"Decomposing diversification effect: evidence from the U.S. property-liability insurance industry"

\begin{tabular}{|c|c|}
\hline AUTHORS & $\begin{array}{l}\text { Xin Che } \\
\text { Andre P. Liebenberg } \\
\text { Ivonne A. Liebenberg } \\
\text { Lawrence S. Powell }\end{array}$ \\
\hline ARTICLE INFO & $\begin{array}{l}\text { Xin Che, Andre P. Liebenberg, Ivonne A. Liebenberg and Lawrence S. Powell } \\
\text { (2017). Decomposing diversification effect: evidence from the U.S. property- } \\
\text { liability insurance industry. Insurance Markets and Companies, 8(1), 16-28. } \\
\text { doi:10.21511/ins.08(1).2017.02 }\end{array}$ \\
\hline DOI & http://dx.doi.org/10.21511/ins.08(1).2017.02 \\
\hline RELEASED ON & Monday, 29 May 2017 \\
\hline RECEIVED ON & Saturday, 25 March 2017 \\
\hline ACCEPTED ON & Tuesday, 16 May 2017 \\
\hline LICENSE & $\begin{array}{l}(c)) \text { EY-NC } \\
\text { This work is licensed under a Creative Commons Attribution-NonCommercial } 4.0 \\
\text { International License }\end{array}$ \\
\hline JOURNAL & "Insurance Markets and Companies" \\
\hline ISSN ONLINE & $2522-9591$ \\
\hline PUBLISHER & LLC "Consulting Publishing Company "Business Perspectives" \\
\hline FOUNDER & LLC "Consulting Publishing Company "Business Perspectives" \\
\hline
\end{tabular}

NUMBER OF REFERENCES

33
NUMBER OF FIGURES

0
$-=-$
$z=-$

NUMBER OF TABLES

3

(C) The author(s) 2023. This publication is an open access article. 
Xin Che (USA), Andre P. Liebenberg (USA), lvonne A. Liebenberg (USA), Lawrence S. Powell (USA)

\title{
Decomposing diversification effect: evidence from the U.S. property- liability insurance industry
}

\begin{abstract}
Prior literature suggests that diversified property-liability $(\mathrm{P} / \mathrm{L})$ insurers underperform their focused counterparts. While most studies focus on insurers' overall performance, there is an absence of evidence regarding whether the underperformance is driven by underwriting or investment profitability. The authors develop and test hypotheses of diversification's separate effect on underwriting and investing in the U.S. property-liability (P/L) insurance industry. It is found that diversified insurers outperform their focused counterparts in terms of investment return, but that they underperform in terms of underwriting profitability. The results are robust to corrections for endogeneity bias and a matched sample analysis.
\end{abstract}

Keywords: diversification, underwriting, investment, conglomeration, strategic focus, property-liability insurance.

JEL Classification: G10, G22, G23.

Received on: $25^{\text {th }}$ of March, 2017.

Accepted on: 16 ${ }^{\text {th }}$ of May, 2017.

\section{Introduction}

Line-of-business (product) diversification is an important corporate strategy for property-liability $(\mathrm{P} / \mathrm{L})$ insurers. An insurance company has the option to diversify across multiple business lines or focus on its core product. The extant literature has investigated effects of this choice on a firm's overall financial performance and provided explanations in many aspects. A striking exclusion from prior empirical analysis is the separate effect of diversification on insurers' two main activities - underwriting and investing. Different from non-financial or non-utility firms whose operating income accounts for the largest proportion of their profits, insurers depend substantially on investment as an income source. While the majority of insurance research suggests that diversification has a negative effect on total performance (e.g., Liebenberg and Sommer, 2008), it is unclear whether the performance change in underwriting or investing is the driving force. Thus, the separate effect of diversification on underwriting and investing performance of property-liability insurers is an important empirical question. The goal of this study is to fill the gap by decomposing the well-known diversification effect.

(C) Xin Che, Andre P. Liebenberg, Ivonne A. Liebenberg, Lawrence S. Powell, 2017.

Xin Che, Doctoral Candidate, Department of Finance, School of Business Administration, University of Mississippi, USA.

Andre P. Liebenberg, Faculty, Department of Finance, School of Business Administration, University of Mississippi, USA.

Ivonne A. Liebenberg, Faculty, Department of Finance, School of Business Administration, University of Mississippi, USA.

Lawrence S. Powell, Director, Alabama Center for Insurance Information and Research, University of Alabama, USA.

This is an Open Access article, distributed under the terms of the Creative Commons Attribution-NonCommercial 4.0 International license, which permits re-use, distribution, and reproduction, provided the materials aren't used for commercial purposes and the original work is properly cited.
There are several ways that diversification can impose costs and/or benefits on underwriting and investing. The potential benefits of diversification for underwriting include scope economies, increased market power, and cross-subsidization. Diversification costs for underwriting include insufficient supervision and inefficient resource allocation (e.g., Lewellen, 1971; Scherer, 1980; Teece, 1980; Grant, Jammine, and Thomas, 1988; Rajan, Servaes, and Zingales, 2000; Martin and Sayrak, 2003).

Diversification can also affect investment decisions, if insurers follow a coordinated risk management approach. Schrand and Unal (1998) propose the coordinated risk management theory that firms use hedging to allocate risk between activities rather than simply to reduce overall risk. To the extent that diversification reduces underwriting risk (from coinsurance benefits), this theory suggests that diversified insurers will increase investment risk. Che and Liebenberg (2017) provide evidence consistent with this theory, as they find that diversified insurers invest in riskier assets and that this relation holds in an event study setting. However, while their analysis suggests a positive relation between diversification and investment risk, it remains an empirical question whether diversifiers are able to realize the higher expected return associated with riskier investments.

We choose to study the P/L insurance industry because insurance firms, as financial intermediaries, have substantial capital to invest, and investment returns account for a large portion of overall firm performance. In addition, reporting requirements in the insurance industry provide very granular data, which help us overcome certain well-known research biases in studies that focus on unregulated industries. First, unlike the general finance literature that is often limited to data on public firms, data are available for both private and public insurance firms. Second, we are able to obtain highly disaggregated premium data across 
all distinct business lines from insurers' statutory filings, while available data for firms in other industries are not nearly as detailed. Finally, because managers of insurance firms have no discretion in allocating premiums in their statutory filings, our data permit us to avoid reporting bias (e.g., minimum unit size, ad-hoc categorization by management, and self-reporting errors) common in research on unregulated industries.

In our univariate ${ }^{1}$ and multivariate analyses, we find that diversified insurers outperform focused insurers in terms of investment profitability (measured as the ratio of investment return to invested assets), but that they underperform in terms of underwriting profitability (measured as the loss ratio). We test the robustness of our results to endogeneity bias by estimating Heckman and two-stage least squares models and find that our results still hold. Our results are also robust to a matched sample analysis ${ }^{2}$.

The remainder of this article proceeds as follows. Section 1 develops our hypothesis and empirical tests. Section 2 describes our data source and sample selection process. Section 3 describesthe empirical approaches we pursue. Section 4 presents the results from multivariate regressions. Final section presents our conclusions.

\section{Hypothesis development and testing}

1.1. Diversification effect on underwriting. The benefits associated with diversification include scope economies, risk reduction, and crosssubsidization. Scope economies consist of both cost scope economies and revenue scope economies. By joining internal resources in production, companies share inputs, distribution channels, expertise, and knowledge about markets and customers in multiple lines to increase the cost efficiency (e.g., Teece, 1980). Revenue scope economies come from customer satisfaction and loyalty due to the shared brand name and reputation (Markides, 1992). With regard to risk, Lewellen (1971) argues that by consolidating businesses with cash flows that are not perfectly correlated, companies can reduce the cash flow volatility through the coinsurance effect. In terms of cross-subsidization, diversification can mitigate losses from failures in some products and markets (Martin and Sayrak, 2003).

The costs associated with diversification include insufficient supervision, inefficient resource allocation, and competition with focused companies. Grant, Jammine and Thomas (1988) find that

\footnotetext{
${ }^{1}$ Univariate test is excluded for parsimony, but available from the authors.

${ }^{2}$ Matched pair analysis is not shown, but available from the authors.
}

managers of highly diversified firms struggle to monitor divisions that are not similar. Inefficient resource allocation creates costs for diversified firms, if internal capital markets transfer funds across divisions in a suboptimal manner (e.g., Rajan, Servaes, and Zingales, 2000), or if diversified firms do not respond adequately to investment opportunities (e.g., Berger and Ofek, 1995). In addition, focused companies may have advantages over diversified firms in information, knowledge, and distribution channels of their core products.

Two competing theories regarding diversification's net effect are the conglomeration hypothesis (that predicts the benefits outweigh the costs) and the strategic focus hypothesis (that predicts the costs outweigh the benefits). Prior studies provide evidence on these two hypotheses in the insurance industry. For example, Hoyt and Trieschmann (1991) study publicly traded insurers and find that specialized (property-liability or life-health) insurers perform better than diversified insurers. Similarly, Liebenberg and Sommer (2008) study P/L insurers and find that single-line insurers outperform multiline insurers by 1 percent in ROA (return on assets) and 2 percent in ROE (return on equity). Elango, $\mathrm{Ma}$, and Pope (2008) also investigate the effect of business diversification on $\mathrm{P} / \mathrm{L}$ insurer performance and find a nonlinear diversification-performance relation that is contingent on geographic diversification.

Given the host of competing effects related to diversification and underwriting performance we offer the following two competing hypotheses:

H1.a (Conglomeration Hypothesis): Diversification is positively related to underwriting performance.

H1.b (Strategic Focus Hypothesis): Diversification is negatively related to underwriting performance.

We test these hypotheses by estimating an empirical model of the following relation:

Underwriting Performance $=f \cdot($ Diversification, controls $) \cdot(1)$

1.1.1. Underwriting performance measure. The most common measure of underwriting performance in the insurance literature is the underwriting loss ratio, LOSS_RATIO. LOSS_RATIO is quotient of incurred losses divided by earned premiums, represented in the following equation:

$$
\text { LOSS_RATIO }=\frac{\text { Incurred Losses }}{\text { Pr emiums Earned }} .
$$

Incurred losses are the sum of losses and loss adjustment expenses anticipated, paid, or owed by an insurance company to its policyholders. Loss 
adjustment expenses include the costs of investigating claims, defending lawsuits, and other administrative costs associated with insured losses. Premiums earned are the proportion of premiums coinciding with the portion of the policy coverage period that has expired. Loss ratio is an inverse measure of performance with a larger loss ratio, indicating lower performance.

1.1.2. Diversification measures. We follow BerryStölzle et al. (2012) in identifying $24 \mathrm{P} / \mathrm{L}$ insurance business lines ${ }^{1}$. Then, we employ two diversification measures. One is a diversification status measure, MULTILINE, which is equal to 1 if an insurer operates in more than one line, and 0 otherwise. The second variable, LINES_DIVERSIFICATION, measures the extent of diversification. LINES_DIVERSIFICATION is the complement of a Herfindahl index of net premiums written (NPW). It is calculated as follows:

LINES _ DIVERSIFICATION $=1-\sum_{i=1}^{24}\left(\frac{N P W_{i, j, t}}{N P W_{i, t}}\right)^{2}$,

where $N P W_{i, j, t}$ denotes the net premiums written in line $j=1, \ldots, 24$ by firm $i$ in year $t$, and $N P W_{i, t}$ denotes the total net premiums written by firm $i$ in year $t$. In the empirical analysis, we, first, use the MULTILINE measure to test if diversified companies are different from non-diversified companies in underwriting performance and investment performance. Then, we use the LINES_DIVERSIFICATION measure to estimate the relation between performance and the extent of diversification.

\subsection{Control variables for underwriting} performance. 1.2.1. Firm size: There is substantial literature on the relation between firm size and performance. Cummins and Nini (2002) find a positive relation between size and performance in the $\mathrm{P} / \mathrm{L}$ insurance industry. Large companies have lower insolvency risk, and they may also possess greater market power than smaller firms. However, the literature yields mixed empirical results on the

\footnotetext{
${ }^{1}$ Consistent with Berry-Stölzle et al. (2012), our study includes the following 24 business lines in P/L insurance industry: Accident and Health (the sum of "Group Accident and Health", "Credit Accident and Health", and "Other Accident and Health"), Aircraft, Auto (the sum of "Private Passenger Auto Liability", "Commercial Auto Liability", and "Auto Physical Damage"), Boiler and Machinery, Burglary and Theft, Commercial Multiple Peril, Credit, Earthquake, Farmowners' Multiple Peril, Financial Guaranty, Fidelity, Fire and Allied lines (the sum of "Fire" and "Allied lines"), Homeowners' Multiple Peril, Inland Marine, International, Medical Professional Liability (the sum of "Medical Malpractice-Occurrence" and "Medical Malpractice-Claims Made"), Mortgage Guaranty, Ocean Marine, Other, Other Liability, Products Liability, Reinsurance (the sum of "Nonproportinal Assumed Property", "Nonproportional Assumed Liability", and "Nonproportional Assumed Financial Lines"), Surety, and Workers' Compensation.
}

relation between size and efficiency (Yuengert, 1993). Therefore, the expected effect of firm size on underwriting performance is not clear. Following Sommer (1996), we use the natural logarithm of total net admitted assets, SIZE, as the proxy of firm size in our analysis.

\subsubsection{Affiliation. Cummins and Sommer (1996) and} Sommer (1996) suggest that consumers are willing to pay a higher price for policies from stand-alone insurers, because an insurance group owns an option to let one or more of its members fail, while protecting the remaining assets of the group. We use a dummy variable, GROUP, to indicate group status. GROUP is equal to 1 if a firm is affiliated and equal to 0 if it is standalone.

\subsubsection{Ownership structure. Managers in stock} firms have incentives to maximize performance at the expense of policyholders. However, the mutual form of ownership structure merges the roles of policyholders and owners. In this way, the incentive conflict between policyholders and owners is mitigated by the mutual structure (Mayers and Smith, 1981). In addition, Cummins, Weiss, and $\mathrm{Zi} \mathrm{(1999)} \mathrm{find} \mathrm{that} \mathrm{stock} \mathrm{firms} \mathrm{are}$ more cost efficient than mutual firms. This suggests that mutual insurance companies and stock insurance companies have different performance objectives. We use a dummy variable, $M U T U A L$, to control for ownership structure. MUTUAL is equal to 1 if the firm is a mutual and equal to 0 if the firm is a stock. We expect a negative relation between $M U T U A L$ and underwriting performance.

1.2.4. Capitalization. Sommer (1996) finds a positive relation between capital-to-asset ratio and the price of insurance. Therefore, we control for capitalization with CAPITAL_RATIO, the ratio of policyholder surplus to total net admitted assets. We expect a positive relation between CAPITAL_RATIO and underwriting performance.

1.2.5. Industry concentration. Chidambaran, Pugel, and Saunders (1997) find a positive relation between industry concentration and underwriting performance in the $\mathrm{P} / \mathrm{L}$ insurance industry. In addition, Montgomery (1985) finds that companies can charge higher prices in more concentrated industries. Liebenberg and Sommer (2008) also report a positive relation between industry concentration and insurers' overall performance, which they measure by ROA. Following Liebenberg and Sommer (2008), we control for industry concentration with INDUSTRY_CONCENTRATION, a weighted average Herfindahl index of net premium written. INDUSTRY_CONCENTRATION is calculated as follows: 


$$
\begin{gathered}
H H I_{j, t}=\sum_{i=1}^{n}\left(\frac{N P W_{i, j, t}}{N P W_{j, t}}\right)^{2}, \\
W_{i, j, t}=\frac{N P W_{i, j, t}}{N P W_{i, t}},
\end{gathered}
$$$$
\text { INDUSTRY_CONCENTRATION } N_{i, t}=\sum_{j=1}^{24} W_{i, j, t} \times H H I_{j, t},
$$

where $N P W_{i, t}$ is net premiums written by firm $i$ in year $t$, and $N P W_{i, j, t}$ is net premiums written in line $j$ by firm $i$ in year $t$. Insurance companies exposed to high industry concentrations may face less competition and, thus, may enjoy more market power. We expect a positive relation between INDUSTRY_CONCENTRATION and underwriting performance.

1.2.6. Geographic diversification. Geographic diversification creates similar benefits in scope economies and risk reduction as product diversification. However, high geographic diversification may also be associated with higher costs due to the physical distance between operations. As evidence of the latter, Mayers and Smith (1988) find that geographically diversified insurance firms have higher costs than geographically focused firms. Liebenberg and Sommer (2008) also report a negative relation between geographic diversification and financial performance. Thus, the relation between geographic diversification and underwriting performance is unclear. We measure geographic diversification with GEO_DIVERSIFICATION, the complement of the Herfindahl index of direct premiums written across the 58 jurisdictions reported by U.S. P/C insurers ${ }^{1}$.

$G_{-}$DIVERSIFICATION $_{i, t}=1-\sum_{k=1}^{58}\left(\frac{D P W_{i, k, t}}{N P W_{i, t}}\right)^{2}$,

where $D P W_{i, t}$ is net premiums written by firm $i$ in year $t$, and $D P W_{i, k, t}$ is net premiums written in the state $k$ by firm $i$ in year $t$.

1.2.7. Business sector. Fiegenbaum and Thomas (1990) find that firm performance differs significantly across groups focusing on personal lines versus commercial lines. We control for differences in business focus with COMMERCIAL, the percentage of net premiums written in commercial lines ${ }^{2}$.

\footnotetext{
${ }^{1}$ The 58 reported locations include the 50 U.S. states, Washington D.C. four U.S. territories, Canada, and other non-U.S. countries.

${ }^{2}$ Commercial lines in our study consist of Fire and Allied lines, Ocean Marine, Inland Marine, Earthquake, Burglary and Theft, Boiler and Machinery, Aggregate Write-ins for Other Lines of Business,
}

1.2. Diversification effect on investing. Diversification reduces idiosyncratic risk by pooling imperfectly correlated cash flows. The Coordinated Risk Management theory (Schrand and Unal, 1998) points out that risk management is not merely synonymous with risk reduction. Rather, it is a process of choosing the optimal amount of risk for a firm to retain. According to this theory, given a bundle of risks within a firm, a change in any one source of risk will affect other risks simultaneously. This happens because firms have an incentive to reallocate risk between activities to achieve the most favorable risk-return trade-off.

Che and Liebenberg (2017) test the coordinated risk management theory in the $\mathrm{P} / \mathrm{L}$ insurance industry. They find cross-sectional evidence that diversified insurers (that likely have lower underwriting risk) tend to hold riskier assets. Moreover, they present event study evidence that diversifying insurers increase asset risk and focusing insurers decrease asset risk $^{3}$. While their study suggests that line-of-business diversification allows for riskier investments (with higher expected returns), it is an empirical question whether the increased investment risk results in higher realized returns ${ }^{4}$. Accordingly, we raise the following hypothesis:

H2 (Coordinated Risk Management Hypothesis): Product diversification is positively related to investment performance.

To test our hypothesis, we estimate a model of the following relation:

$$
\text { Investment Performance }=f \cdot(\text { Diversification, controls }) \text {. }
$$

1.2.1. Investment performance measure. We measure the investment performance of an insurance company by its investment return, INVESTMENT_RETURN. The investment return is calculated by dividing net investment gain (loss) by total cash and invested assets. The formula appears below:

$$
\text { INVESTMENT_RETURN }=\frac{\text { Net Investment Gain (Loss) }}{\text { Total Cash and Invested Assets }} .
$$

Commercial Multiple Peril, Medical Malpractice, Workers' Compensation, Products Liability, Other liability, Commercial Auto Liability, Aircraft, International, and Reinsurance.

3 Similarly, McShane, Zhang, and Cox (2012), find evidence that insurers coordinate derivatives hedging and reinsurance usage.

4 While theory predicts a positive risk-return relation, empirical evidence is lacking. Liebenberg and Sommer (2008) include the standard deviation of ROA as a risk control in their regressions where ROA is the dependent variable and find no relation in 3 of 4 models and a positive relation in only 1 model. 
1.2.2. Diversification measures. We use the same diversification measures employed in the underwriting performance analysis. Diversification status is measured by the dummy variable, MULTILINE, and the extent of diversification, LINES_DIVERSIFICATION, is the complement of a Herfindahl index of net premiums by line of business.

\subsection{Control variables for investment} performance. 1.3.1. Firm size. All else equal, large insurance companies may have advantages over small firms in investment management (Pottier, 2007). This may occur because firms with more assets can deploy numerous and complex investment strategies compared to firms with fewer assets. This potentially allows strategies that increase return for the same level of risk. We measure firm size with SIZE, the natural logarithm of total net admitted assets. We expect a positive relation between investment return and SIZE.

\subsubsection{Geographic diversification. Geographic} diversification also reduces risk by pooling uncorrelated cash flows. Therefore, the Coordinated Risk Management Hypothesis also suggests that geographically diversified insurers should have greater capacity to take risk in their investment portfolios to achieve higher expected returns. We measure the geographical diversification with GEO_DIVERSIFICATION, the modified Herfindahl index of direct premiums written across 58 locations reported in the statutory filing. We expect a positive relation between geographic diversification and investment return.

1.3.3. Capitalization. Consistent with the Coordinated Risk Management Hypothesis, Che and Liebenberg (2017) find that highly levered insurance companies have lower asset risk. Therefore, we expect a positive relation between capitalization and investment return. The variable, CAPITAL_RATIO, is calculated as policyholder surplus divided by total net admitted assets.

1.3.4. Reinsurance. Insurance companies can use reinsurance to reduce insolvency risk (Mayers and Smith, 1990). With lower insolvency risk, the Coordinated Risk Management Hypothesis implies that insurers can increase risk in their investment portfolios (Lee, Mayers, and Smith, 1997). However, Che and Liebenberg (2017) find that reinsurance is negatively related to the asset risk, and they suggest that rather than a substitute for business line diversification, reinsurance serves as a signal of risk aversion. Thus, the relation between investment return and reinsurance ceded is unclear. We measure reinsurance activity with REINSURANCE_RATIO, the ratio of premiums ceded to non-affiliated firms divided by the sum of direct premiums written and reinsurance assumed from non-affiliates.

1.3.5. Affiliation. Che and Liebenberg (2017) find evidence that affiliated insurance companies hold riskier assets. Therefore, we expect affiliated firms to have higher investment returns than unaffiliated firms. We measure affiliation status with a dummy variable, GROUP, which is equal to 1 if the observation is a group and 0 if it is a standalone company.

1.3.6. Ownership structure. Mutual insurers tend to hold more capital than stock insurers, because their access to capital markets is limited. All else equal, we expect insurers with more capital (less leverage) to take more investment risk. However, while stock insurers have easier access to external capital markets, they are also subject to monitoring by bondholders and equity holders. This leaves us without a clear, ex ante expectation for the effect of ownership structure on investment risk. Empirically, Yu et al. (2008) show that stock insurers take less asset risk than mutual insurers. Hence, we expect mutual insurers to have higher investment returns than stock insurers. We measure ownership structure with a dummy variable, MUTUAL, which is equal to 1 if a company is a mutual firm and 0 if it is a stock firm.

1.3.7. Long-tail lines. Insurance companies that have more business in long-tail lines are inclined to take less risk in order to achieve a balanced portfolio (Yu et al., 2008). Thus, we expect the proportion premiums in long-tail lines of business ${ }^{1}$ to be negatively related to investment return. The variable, $L O N G \_T A I L$, is net premiums written in long-tail lines as a percentage of total net premiums written.

\section{Data and sample}

We obtain an initial sample of $\mathrm{P} / \mathrm{L}$ insurance companies from the National Association of Insurance Commissioners (NAIC) InfoPro ${ }^{2}$ database for years 1997 through 2013. This period includes both hard market and soft market conditions (see Insurance Information Institute, 2015). Berry-Stölzle et al. (2012) note the benefits of including both soft and hard market conditions in a sample period of $\mathrm{P} / \mathrm{L}$ insurance companies. In

\footnotetext{
${ }^{1}$ Our classification of long-tail business lines is consistent with Sommer (1996), Pottier and Sommer (1999), and Yu et al. (2008). The long-tail business lines in our study include Commercial Auto Liability, Private Passenger Auto Liability, Other Liability, Farmowners' Multiple Peril, Homeowners' Multiple Peril, Commercial Multiple Peril, Medical Professional Liability, Workers' Compensation, Aircraft, and Boiler and Machinery.

${ }^{2}$ NAIC data are used with permission. NAIC does not endorse results gleaned from their data.
} 
a soft market, coverage is more available, and insurance premiums are more reasonable, while in a hard market, availability of coverage is limited, and prices increase (Weiss, 2007).

Next, because insurance companies implement corporate strategies and practice risk management at the group level, rather than the individual firm level (Berger, Cummins, and Weiss, 2000; Liebenberg and Sommer, 2008; Elango, Ma, and Pope, 2008; and Berry-Stölzle et al., 2012), we aggregate the affiliated insurer observations to the group level. Then, we screen out observations with negative total net admitted assets, and negative net premiums written. Consistent with prior literature, we limit our sample to mutual and stock insurers, discarding a small number of Lloyd's associations, reciprocal exchanges, and risk retention groups. Finally, we delete observations for which the two dependent variables exceed the first and ninety-ninth percentiles to mitigate the effect of obvious outliers. Our data screening yields a final sample with 10,863 firm-year observations. Table 1 presents summary statistics.

Table 1. Summary statistics

\begin{tabular}{|c|c|c|c|c|c|c|}
\hline Variable name & $N$ & Mean & Median & Min & Max & $S D$ \\
\hline \multicolumn{7}{|c|}{ Underwriting performance measure: } \\
\hline LOSS_RATIO & 10,863 & 0.6483 & 0.6660 & 0.0001 & 1.6124 & 0.2217 \\
\hline \multicolumn{7}{|c|}{ Investment performance measure: } \\
\hline INVESTMENT_RETURN & 10,863 & 0.0408 & 0.0391 & -0.0284 & 0.2989 & 0.0224 \\
\hline \multicolumn{7}{|c|}{ Diversification measure: } \\
\hline MULTILINE & 10,863 & 0.7405 & 1.0000 & 0.0000 & 1.0000 & 0.4384 \\
\hline LINES_DIVERSIFICATION & 10,863 & 0.3639 & 0.4194 & 0.0000 & 0.9999 & 0.3053 \\
\hline \multicolumn{7}{|l|}{ Control variables: } \\
\hline SIZE & 10,863 & 18.0222 & 17.6949 & 11.9440 & 26.2667 & 2.3962 \\
\hline GROUP & 10,863 & 0.3115 & 0.0000 & 0.0000 & 1.0000 & 0.4631 \\
\hline MUTUAL & 10,863 & 0.4798 & 0.0000 & 0.0000 & 1.0000 & 0.4996 \\
\hline CAPITAL_RATIO & 10,863 & 0.4741 & 0.4394 & 0.0002 & 0.9999 & 0.1897 \\
\hline INDUSTRY_CONCENTRATION & 10,863 & 0.0577 & 0.0564 & 0.0006 & 0.5899 & 0.0234 \\
\hline GEO_DIVERSIFICATION & 10,863 & 0.3201 & 0.0480 & 0.0000 & 0.9654 & 0.3734 \\
\hline COMMERCIAL & 10,863 & 0.5292 & 0.5081 & 0.0000 & 1.0000 & 0.3848 \\
\hline REINSURANCE_RATIO & 10,863 & 0.2191 & 0.1563 & 0.0000 & 0.9959 & 0.2069 \\
\hline LONG TAIL & 10,863 & 0.7661 & 0.9202 & 0.0000 & 1.0000 & 0.3307 \\
\hline
\end{tabular}

\section{Empirical methods}

We employ several univariate and multivariate statistical procedures to test our hypotheses. While the univariate tests largely serve to motivate multivariate tests, we are encouraged that results from simple mean and median comparisons are consistent with multivariate results ${ }^{1}$.

Our most powerful and reliable tests of hypotheses H1.a (Conglomeration Hypothesis), H1.b (Strategic Focus Hypothesis), and $\mathrm{H} 2$ (Coordinated Risk Management Hypothesis), use three variations of multiple regression analysis. We begin with ordinary least squares (OLS) regression to calculate baseline results for comparison and to test for empirical concerns. The underwriting loss ratio, LOSS_RATIO, and investment return measure, INVESTMENT_RETURN, serve as the dependent

\footnotetext{
${ }^{1}$ For parsimony, results from univariate tests, and some multivariate tests are not presented. These results are available by request from the authors.
}

variables in each set of regression models. Our independent variables of primary interest are the two measures of diversification. MULTILINE is an indicator variable equal to 1 if the firm underwrites more than one line of insurance. LINES_DIVERSIFICATION is a continuous measure of diversification equal to the complement of a Herfindahl index of net premiums written by line of business. In addition, we control for other factors that are correlated with loss ratio. Following Liebenberg and Sommer (2008), we also control for years and the states, in which each firm operates to diminish influence of the underwriting cycle over time, and differences in regulation and risk exposure across states. These factors enter our regression model as year fixed effects and a series of 57 dummy variables equal to 1 if the firm operates in each coinciding location ${ }^{2}$. We estimate the following regression models:

\footnotetext{
${ }^{2}$ Results are available from the authors. We omit one year and one location to avoid singularity in the regression matrix. The choice of omitted dummy variables is random and does not affect results.
} 


$$
\begin{aligned}
& \text { LOSS }_{-} \text {RATIO }_{i, t}=\alpha_{t}+\beta_{1} \text { MULTILINE }_{i, t}+\beta_{2} \text { SIZE }_{i, t}+\beta_{3} \text { GROUP }_{i, t}+\beta_{4} \text { MUTUAL }_{i, t}+ \\
& +\beta_{5} \text { CAPITAL_RATIO }_{i, t}+\beta_{6} \text { INDUSTRY_CONC }_{i, t}+\beta_{7} G E O_{-} D I V_{i, t}+ \\
& +\beta_{8} \text { COMMERCIAL }_{i, t}+\beta_{9-24} \text { YEAR }_{t}+\beta_{25-82} \text { STATE }_{i, t} .
\end{aligned}
$$$$
\text { INVESTMENT_RETURN } N_{i, t}=\alpha_{t}+\beta_{1} \text { MULTILINE }_{i, t}+\beta_{2} \text { SIZE }_{i, t}+\beta_{3} G E O_{-} \text {DIV }_{i, t}+
$$$$
+\beta_{4} \text { CAPITAL_RATIO }{ }_{i, t}+\beta_{5} \text { CREINSURANCE_RATIO }{ }_{i, t}+\beta_{6} \text { GROUP }_{i, t}+\beta_{7} \text { MUTUAL }_{i, t}+
$$$$
+\beta_{8} L O N G_{-} T A I L_{i, t}+\beta_{9-24} Y_{E A R_{t}}+\beta_{25-82} \text { STATE }_{i, t} .
$$

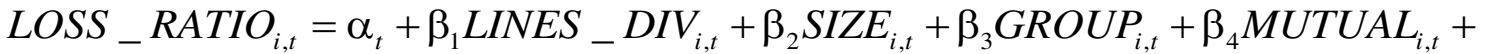$$
+\beta_{5} \text { CAPITAL_RATIO }{ }_{i, t}+\beta_{6} I N D U S T R Y \_C O N C_{i, t}+\beta_{7} G E O_{-} D I V_{i, t}+
$$$$
+\beta_{8} \text { COMMERCIAL }_{i, t}+\beta_{9-24} \text { YEAR }_{t}+\beta_{25-82} \text { STATE }_{i, t} \text {. }
$$

$$
\begin{aligned}
& \text { INVESTMENT_RETURN } N_{i, t}=\alpha_{t}+\beta_{1} \text { LINES _ DIV }_{i, t}+\beta_{2} \text { SIZE }_{i, t}+\beta_{3} G E O_{-} \text {DIV } V_{i, t}+ \\
& +\beta_{4} \text { CAPITAL_RATIO }_{i, t}+\beta_{5} \text { REINSURANCE }_{i, t}+\beta_{6} \text { GROUP }_{i, t}+\beta_{7} \text { MUTUAL }_{i, t}+ \\
& +\beta_{8} L O N G_{-} T A I L_{i, t}+\beta_{9-24} Y_{E A R_{t}}+\beta_{25-82} \operatorname{STATE}_{i, t} \text {. }
\end{aligned}
$$

The diversification literature in general finance (e.g., Laeven and Levine, 2007) and insurance (e.g., Liebenberg and Sommer, 2008) both suggest endogeneity in the diversification measure. We conduct a Hausman test to confirm the existence of endogeneity. For the MULTILINE measure, the t-statistics from the Hausman test are significant at the $1 \%$ level in the both underwriting performance regression and investment performance regression, rejecting the null hypothesis of exogeneity. Therefore, we adopt both a Heckman treatment effect mode and a two-stage least squares (2SLS) model. Specifically, the Heckman treatment effect model estimates a self-selection parameter from a first-stage logit regression and includes the parameter estimate in the second stage to correct for the self-selection bias ${ }^{1}$.

Successful instruments for Heckman and 2SLS must meet two conditions, the exogeneity condition and the relevance condition. Liebenberg and Sommer (2008) propose three valid instruments for a diversification measure, firm age, exposure to competition with focused companies, and reinsurance ratio. Defining these variables, $A G E$ is the natural logarithm of firm age, REINSURANCE_RATIO is the ratio of reinsurance premium ceded to direct premiums written and reinsurance assumed, and FOCUS_INDEX (described in more detail below) is an index of the percentage of firm's competitors that are not diversified by line of business. We test the relevance of these instruments in our model with a Wald test. Then, we assess instrument validity with Hansen's J-tests for overidentifying restrictions. In addition, note that REINSURANCE_RATIO is used as a control variable in our investment performance

${ }^{1}$ Self-selection bias is a special case of endogeneity. analysis; therefore, we do not consider the reinsurance ratio as a candidate for the instruments in the investment performance regressions. Our tests show that FOCUS_INDEX is a suitable instrument. The calculation of FOCUS_INDEX is as follows:

$$
\begin{gathered}
w_{i, j, t}=\frac{N P W_{i, j, t}}{N P W_{i, t}}, \text { and } \\
\text { SINGLE } E_{j, t}=\frac{N P W \text { by Insurers Focused on Line } j}{N P W_{j, t}}, \\
\text { FOCUS INDEX }=\sum_{j=1}^{24} w_{i, j, t} \times \text { SINGLE }_{j, t},
\end{gathered}
$$

where $N P W_{i, t}$ is net premiums written by firm $i$ in year $t, N P W_{j, t}$ is total net premiums written in line $j$ in year $t$, and $N P W_{i, j, t}$ is net premiums written in line $j$ by firm $i$ in year $t$.

For the models including the LINES_DIVERSIFICATION measure, the t-statistic from the Hausman test is only significant in the underwriting performance regression. We cannot reject the null hypothesis of exogeneity in the investment performance regression. Thus, we consider the endogeneity problem solely in the underwriting performance regression. Using the aforementioned instrument tests, we find that FOCUS_INDEX is a successful instrument for LINES_DIVERSIFICATION. Therefore, we use FOCUS_INDEX as an instrument in the 2SLS regression for underwriting performance analysis.

Following Campa and Kedia (2002), we also considered a two-way fixed-effects model to address endogeneity concerns. However, our diversification measures do not have sufficient within-firm variation to estimate a two-way fixed effects model. 
Hence, we adjust standard errors for firm-level clustering to address the panel nature of our data.

\section{Multivariate analysis}

Table 2 (see Appendix) presents the results from multivariate regressions of underwriting performance on diversification. In the regressions using our binary diversification measure, the coefficient estimates on MULTILINE are consistently positive and significant across OLS, Heckman, and 2SLS estimations, demonstrating that diversified companies have higher loss ratios than focused firms ${ }^{1}$. In other words, diversified firms underperform focused firms in underwriting. The coefficient on our continuous measure of diversification (LINES_DIVERSIFICATION) is also positive and significant in each model. Thus, the dispersion of net premiums written is negatively correlated with underwriting performance. This is consistent with the strategic focus hypothesis.

Besides our variable of interest, the coefficient estimates on our control variables are also reported. We find that SIZE is positively and significantly related to the loss ratio in all regressions, implying that small companies have better underwriting performance. The coefficient estimate on GROUP is only positive and significant in one regression, suggesting that there is little evidence that affiliation has effects on underwriting performance. The coefficient estimate on MUTUAL is positive and significant in the regressions other than the 2SLS estimations. Therefore, we do not find consistent evidence on whether stock firms outperform mutual firms in terms of underwriting. We find a significantly negative relation between CAPITAL_RATIO and loss ratio, and the relation isconsistent in each regression model. Thus, insurers with greater capitalization have better underwriting performance, supporting the hypothesis that an insurance firm that is more capitalized can charge a higher price on customers because of less insolvency risk. The coefficient estimates on INDUSTRY_CONCENTRATION and GEO_DIVERSIFICATION are insignificant in all regressions. Finally, we find a positive and significant relation between commercial line business (COMMERCIAL) and loss ratio in all regressions, implying that firms doing more business on commercial lines have lower underwriting performance.

Table 3 (see Appendix) presents the results from the multivariate regressions of investment performance on diversification. We find that the coefficient estimate on MULTILINE is consistently positive and

\footnotetext{
Robustness tests using matched-pair sample and difference-indifference regression techniques to control for fundamental differences between diversifiers and non-diversifiers also support this conclusion. Results are available from the authors.
}

significant in all regressions ${ }^{2}$. However, it is not significant on LINES_DIVERSIFICATION. The positive relation between investment return and MULTILINE implies that diversified firms have higher investment returns than non-diversified firms, and the insignificant coefficient estimate on LINES_DIVERSIFICATION suggests that investment return is not related to the diversification extent. We also find that investment return is positively and significantly related to SIZE. Thus, consistent with Pottier (2007), large companies have higher investment return than small firms. We do not find a significant relation between GEO_DIVERSIFICATION and investment return. As expected, we find a positive and significant relation between CAPITAL_RATIO and investment performance. Consistent with Chen and Liebenberg's (2017) idea that reinsurance serves as a signal of risk aversion, we find that the REINSURANCE_RATIO is negatively and significantly related to the investment return in all regression models. The coefficient estimate on GROUP is consistently negative and significant across all regression models. Thus, the relation between affiliation and investment return is opposite of what we expect. Lastly, the results with respect to ownership and long tail business are not statistically significant.

\section{Conclusion}

Most prior insurance literature finds that diversification has a negative effect on total insurer performance, but does not examine the separate effect on insurers' two main income sources underwriting and investing. Theory suggests differential diversification effects for each of these activities. While the strategic focus hypothesis predicts a negative effect of diversification on underwriting profitability, the coordinated risk management theory suggests a positive diversification effect on investment return. Our study contributes to the literature by investigating the separate effect on investment and underwriting and shedding light on the source of the welldocumented diversification penalty for $\mathrm{P} / \mathrm{L}$ insurers.

We use regression analysis to estimate the effect of diversification status and extent on underwriting profitability and on investment return. Our results show that diversified insurers have higher investment returns than focused insurers but they have lower underwriting profitability. Our results are robust to corrections for endogeneity bias and a matched sample analysis.

\footnotetext{
2 Robustness tests using matched-pair samples and difference-indifference regression techniques to control for fundamental differences between diversifiers and non-diversifiers are consistent with this finding. Results are available from the authors.
} 


\section{References}

1. Berger, A. N., Cummins, J. D., \& Weiss, M. A. (2000). Conglomeration versus Strategic Focus: Evidence from the Insurance Industry. Journal of Financial Intermediation, 9, 323-362.

2. Berger, P. G., \& Ofek, E. (1995). Diversification's Effect on Firm Value. Journal of Financial Economics, 37, $39-65$.

3. Berry-Stölzle, T. R., Liebenberg, A. P., Ruhland, J. S., \& Sommer, D. W. (2012). Determinants of Corporate Diversification: Evidence from the Property-Liability Insurance Industry. Journal of Risk and Insurance, 79, 381-413.

4. Campa, J. M, \& Kedia, S. (2002). Explaining the Diversification Discount. Journal of Finance, 57, $1731-1762$.

5. Che, X., \& Liebenberg, A. P. (2017). Effects of Business Diversification on Asset Risk-Taking: Evidence from the U.S. Property-Liability Insurance Industry. Journal of Banking and Finance,77, 122-136

6. Chidambaran, N. K., Pugel T. A., \& Saunders A. (1997). An Investigation of the Performance of the U.S. Property-Liability Insurance Industry. Journal of Risk and Insurance, 64, 371-381.

7. Cummins, J. D., \& Nini, G. (2002). Optimal Capital Utilization by Financial Firms: Evidence from the PropertyLiability Insurance Industry. Journal of Financial Services Research, 21, 15-53.

8. Cummins, D., \& Sommer, D. (1996). Capital and Risk in Property-Liability Insurance Markets. Journal of Banking and Finance, 20, 1069-1092.

9. Cummins, J. D., Weiss, M. A., \& Zi, H. (1999). Organizational Form and Efficiency: The Coexistence of Stock and Mutual Property-Liability Insurers. Management Science, 45, 1254-1269.

10. Elango, B., Ma, Y., \& Pope, N. (2008). An Investigation into the Diversification-Performance Relationship in the U.S. Property-Liability Insurance Company. Journal of Risk and Insurance, 75, 567-591.

11. Fiegenbaum, A., \& Thomas, H. (1990). Strategic Groups and Performance: The U.S. Insurance Industry, $1970-84$. Strategic Management Journal, 11, 197-215.

12. Grant, R. M., Jammine, A. P., \& Thomas, H. (1988). Diversity, Diversification, and Profitability among British Manufacturing Companies. Academy of Management Journal, 31, 771-801.

13. Hoyt, R. E., \& Trieschmann, J. S. (1991). Risk/Return Relationships for Life-Health, Property-Liability, and Diversified Insurers. Journal of Risk and Insurance, 58, 322-330.

14. Insurance Information Institute. (2015). Facts and Statistics: Property/Casualty Insurance Cycle. Retrieved from http://www.iii.org/fact-statistic/property-casualty-insurance-cycle

15. Laeven, L., \& Levine, R. (2007). Is There a Diversification Discount in Financial Conglomerates? Journal of Financial Economics, 85, 331-367.

16. Lee, S., Mayers, D., \& Smith, C. W. (1997). Guaranty Funds and Risk-Taking Evidence from the Insurance Industry. Journal of Financial Economics, 44, 3-24.

17. Lewellen, W. G. (1971). A Pure Financial Rationale for the Conglomerate Merger. Journal of Finance, 26, 521-537.

18. Liebenberg, A. P., \& Sommer, D. W. (2008). Effects of Corporate Diversification: Evidence from the PropertyLiability Insurance Industry. Journal of Risk and Insurance, 75, 893-919.

19. Martin, J. D., \& Sayrak, A. (2003). Corporate Diversification and Shareholder Value: A Survey of Recent Literature. Journal of Corporate Finance, 9, 37-57.

20. Markides, C. C. (1992). Consequences of Corporate Refocusing: Ex Ante Evidence. Academy of Management Journal, 35, 398-412.

21. Mayers, D., \& Smith, C. W. (1981). Contractual Provisions, Organizational Structure, and Conflict Control in Insurance Markets. Journal of Business, 54, 407-434.

22. Mayers, D., \& Smith, C. W. (1988). Ownership Structure Across Lines of Property-Casualty Insurance. Journal of Law and Economics, 31, 351-378.

23. Mayers, D., \& Smith, C. W. (1990). On the Corporate Demand for Insurance: Evidence from the Reinsurance Market. Journal of Business, 63, 19-40.

24. Montgomery, C. A. (1985). Product-Market Diversification and Market Power. Academy of Management Journal, 28, 789-798.

25. Rajan, R., Servaes, H., \& Zingales, L. (2000). The Cost of Diversity: The Diversification Discount and Inefficient Investment. Journal of Finance, 55, 35-80.

26. Pottier, S. W. (2007). The Determinants of Private Debt Holdings: Evidence from the Life Insurance Industry. Journal of Risk and Insurance, 74, 591-612.

27. Scherer, F. M. (1980). Industrial Market Structure and Economic Performance. Chicago: Rand McNally.

28. Schrand, C. M., \& Unal, H. (1998). Hedging and Coordinated Risk Management: Evidence from Thrift Conversions. Journal of Finance, 53, 979-1013.

29. Sommer, D. W. (1996). The Impact of Firm Risk on Property-Liability Insurance Prices. Journal of Risk and Insurance, 63, 501-514.

30. Teece, D. J. (1980). Economics of Scope and the Scope of the Enterprise. Journal of Economic Behavior and Organization, 1, 223-247.

31. Weiss, M. A. (2007). Underwriting Cycles: A Synthesis and Further Directions. Journal of Insurance Issues, $30,31-46$.

32. Yu, T., Lin, B., Oppenheimer, H. R., \& Chen, X. (2008). Intangible Assets and First Risk-taking: An Analysis of Property and Liability Insurance Firms. Risk Management and Insurance Review, 11, 157-178.

33. Yuengert, A. M. (1993). The Measurement of Efficiency in Life Insurance Estimates of a Mixed Normal-Gamma Error Model. Journal of Banking and Finance, 17, 483-496. 


\section{Appendix}

Table 2. Diversification effect on underwriting performance

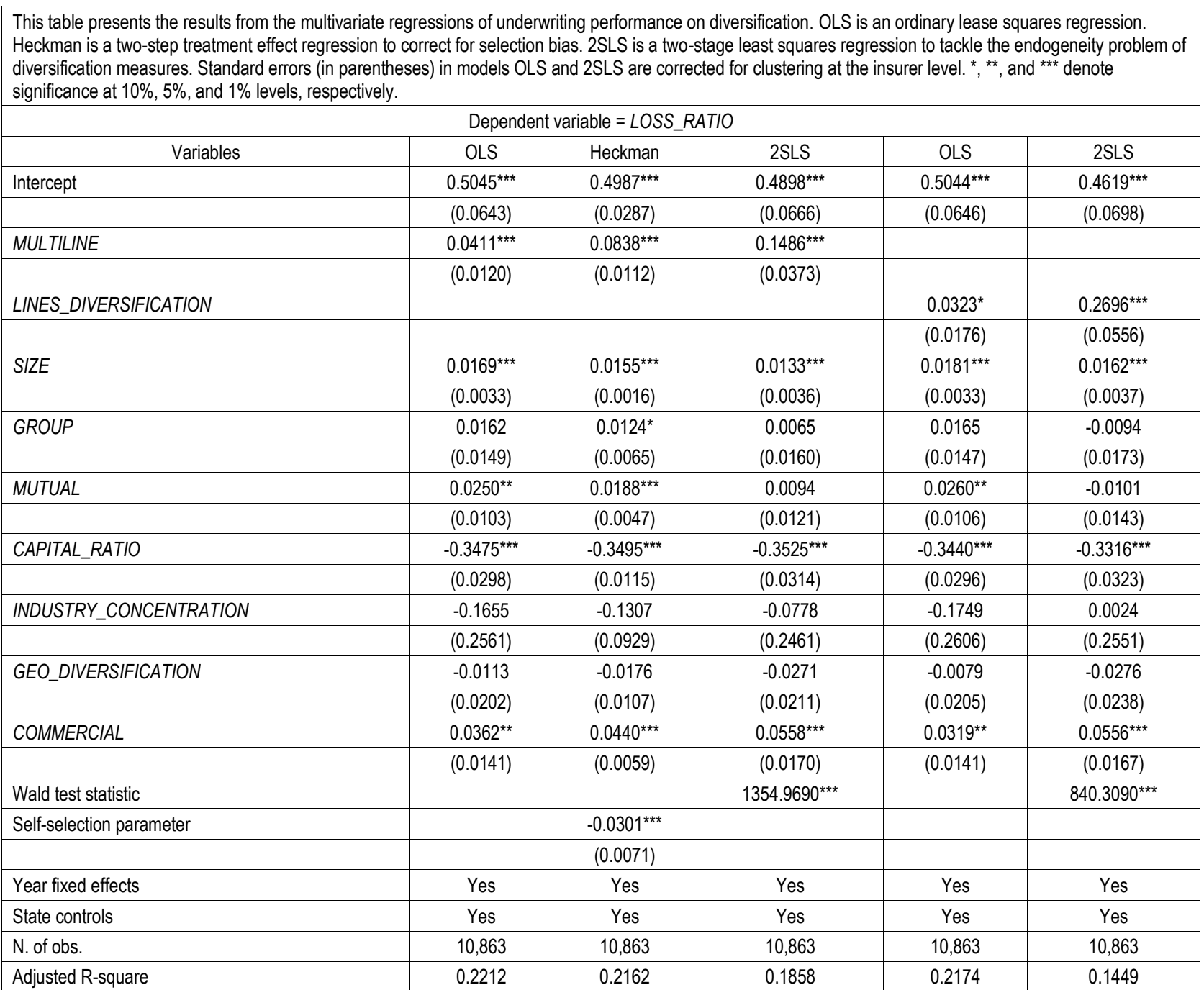

Table 3. Diversification effect on investment performance

This table presents the results from the multivariate regressions of investment performance on diversification. OLS is an ordinary lease squares regression. Heckman is a two-step treatment effect regression to correct for selection bias. 2SLS is a two-stage least squares regression to tackle the endogeneity problem of diversification measures. Standard errors in OLS and 2SLS models are corrected for clustering at the insurer level. ${ }^{*},{ }^{* *}$, and ${ }^{* \star *}$ denote significance at $10 \%, 5 \%$, and $1 \%$ levels, respectively.

\begin{tabular}{|c|c|c|c|c|}
\hline \multicolumn{5}{|c|}{ Dependent variable $=$ INVESTMENT_RETURN } \\
\hline Variables & OLS & Heckman & 2SLS & OLS \\
\hline \multirow[t]{2}{*}{ Intercept } & $0.0202^{* * *}$ & $0.0222^{* * *}$ & $0.0228^{* * *}$ & $0.0195^{\star \star *}$ \\
\hline & $(0.0049)$ & $(0.0028)$ & $(0.0050)$ & (0.0049) \\
\hline \multirow[t]{2}{*}{ MULTILINE } & $0.0017^{* *}$ & $0.0067^{* * *}$ & $0.0081^{* * *}$ & \\
\hline & $(0.0008)$ & $(0.0011)$ & $(0.0020)$ & \\
\hline \multirow[t]{2}{*}{ LINES_DIVERSIFICATION } & & & & 0.0003 \\
\hline & & & & $(0.0012)$ \\
\hline \multirow[t]{2}{*}{ SIZE } & $0.0022^{* * *}$ & $0.0020^{* \star *}$ & $0.0020^{* * *}$ & $0.0023^{\star * *}$ \\
\hline & $(0.0003)$ & $(0.0002)$ & $(0.0003)$ & $(0.0003)$ \\
\hline \multirow[t]{2}{*}{ GEO_DIVERSIFICATION } & 0.0008 & 0.0000 & -0.0002 & 0.0011 \\
\hline & $(0.0017)$ & $(0.0010)$ & $(0.0017)$ & $(0.0017)$ \\
\hline \multirow[t]{2}{*}{ CAPITAL_RATIO } & $0.0050^{* *}$ & $0.0040^{\star * \star}$ & $0.0037^{*}$ & $0.0053^{* *}$ \\
\hline & $(0.0020)$ & $(0.0012)$ & $(0.0021)$ & $(0.0020)$ \\
\hline \multirow[t]{2}{*}{ REINSURANCE_RATIO } & $-0.0048^{\star * *}$ & $-0.0070^{* * *}$ & $-0.0077^{\star \star \star}$ & $-0.0042^{* *}$ \\
\hline & $(0.0017)$ & $(0.0010)$ & $(0.0019)$ & $(0.0016)$ \\
\hline \multirow[t]{2}{*}{ GROUP } & $-0.0045^{\text {*** }}$ & $-0.0051^{* * *}$ & $-0.0052^{* * *}$ & $-0.0044^{* * *}$ \\
\hline & $(0.0010)$ & $(0.0006)$ & $(0.0010)$ & $(0.0010)$ \\
\hline
\end{tabular}


Table 3 (cont.). Diversification effect on investment performance

\begin{tabular}{|l|c|c|c|c|}
\hline \multicolumn{1}{|c|}{ Variables } & OLS & Heckman & 2SLS & OLS \\
\hline MUTUAL & 0.0005 & -0.0001 & -0.0003 & 0.0007 \\
\hline & $(0.0007)$ & $(0.0004)$ & $(0.0008)$ & $(0.0007)$ \\
\hline LONG_TAIL & 0.0011 & 0.0003 & 0.0001 & 0.0013 \\
\hline & $(0.0011)$ & $(0.0007)$ & $(0.0012)$ & $(0.0012)$ \\
\hline Wald test statistic & & & $1144.1920^{* * *}$ & \\
\hline Self-selection parameter & & $-0.0035^{* * *}$ & & \\
\hline & & $(0.0007)$ & & \\
\hline Year fixed effects & Yes & Yes & Yes & Yes \\
\hline State controls & Yes & Yes & Yes & Yes \\
\hline N. of obs. & 10,863 & 10,863 & 10,863 & 10,863 \\
\hline Adjusted R-square & 0.3263 & 0.3267 & 0.3144 & 0.3255 \\
\hline
\end{tabular}




\begin{tabular}{|c|c|c|c|c|c|c|c|c|c|c|c|}
\hline Voluntary types of insurance & 2005 & 2006 & 2007 & 2008 & 2009 & 2010 & 2011 & 2012 & 2013 & 2014 & 2015 \\
\hline Accident insurance & 111793.9 & 184561.0 & 276146.5 & 417808.1 & 287792.3 & 348881.7 & 346727.3 & 756377.8 & 990870.6 & 637974.5 & 309443.7 \\
\hline Medical insurance & 253962.4 & 353157.2 & 452830.0 & 636346.6 & 724128.6 & 809363.9 & 736311.5 & 1280060.8 & 1395662.6 & 1507146.9 & 1441852.1 \\
\hline Health insurance & 81261.0 & 93659.3 & 111264.5 & 165034.1 & 126797.7 & 138908.2 & 121643.2 & 316343.2 & 372076.5 & 300943.7 & 201558.9 \\
\hline Railway transport insurance & 232821.7 & 4348.9 & 13608.2 & 72358.5 & 25077.4 & 18712.6 & 58006.7 & 68805.0 & 54511.0 & 41941.5 & 41814.5 \\
\hline Land transport insurance & 1039177.7 & 1900058.7 & 3403873.0 & 4887040.2 & 3448112.1 & 3064987.5 & 1800307.1 & 3243068.8 & 3270423.0 & 3059813.4 & 2571611.4 \\
\hline Air transport insurance & 5848.5 & 8222.0 & 7488.4 & 10187.0 & 18443.7 & 18202.3 & 2863.5 & 5575.5 & 9649.8 & 11079.6 & 14489.3 \\
\hline Water transport insurance & 18380.9 & 21509.9 & 34081.9 & 31423.5 & 33909.8 & 28211.3 & 8596.4 & 32615.4 & 22812.7 & 21326.9 & 12907.9 \\
\hline Cargo and baggage insurance & 582942.8 & 483278.9 & 532950.2 & 699678.1 & 378596.7 & 801675.9 & 657462.3 & 948702.4 & 965656.2 & 860404.2 & 1197636.6 \\
\hline Insurance from fire risks and risks of natural disasters & 759564.4 & 927128.1 & 1142878.7 & 1204612.7 & 930997.5 & 1156295.8 & 1015813.4 & 1830040.0 & 1649286.7 & 1250366.3 & 980147.4 \\
\hline Property insurance & 984700.4 & 1194267.8 & 1534129.7 & 1630413.4 & 1489866.3 & 1680822.1 & 1027353.8 & 2606524.6 & 2489676.7 & 2045130.4 & 1617323.1 \\
\hline Civil liability insurance of the owners of land transport & 45715.2 & 46898.7 & 68262.2 & 71886.5 & 56854.4 & 81488.9 & 42464.7 & 80386.7 & 92746.2 & 105934.1 & 148631.9 \\
\hline Liability insurance of the owners of air transport & 1954.5 & 1453.6 & -225.3 & 1624.1 & 16407.9 & 22627.1 & -19144.8 & 5010.5 & 595.0 & 2544.3 & 8348.5 \\
\hline Liability insurance of the owners of water transport & 6652.1 & 7620.4 & 7562.2 & 8122.5 & 7212.4 & 6798.6 & 644.4 & 7040.2 & 5208.0 & 6409.6 & 4849.0 \\
\hline Third-party liability coverage & 190157.6 & 226778.9 & 283125.6 & 434077.2 & 485832.5 & 505916.5 & 313921.8 & 940289.0 & 1033863.0 & 671720.9 & 745788.6 \\
\hline Credit insurance & 371683.4 & 336574.9 & 598682.6 & 1178680.0 & 744296.6 & 256445.2 & 185209.6 & 498020.7 & 683963.5 & 388209.1 & 214979.2 \\
\hline Investment insurance & 13385.3 & 2109.0 & 2141.9 & 65.3 & -14.7 & 2.0 & -40628.1 & 4.9 & 6168.4 & 9.5 & 1.0 \\
\hline Insurance of financial risks & 1473505.0 & 1494939.7 & 1658365.6 & 1395588.3 & 905077.3 & 755681.4 & 1257832.3 & 2098397.2 & 2401323.2 & 2019078.3 & 1811564.4 \\
\hline Insurance of court expenses & 45.9 & 39.9 & 7.2 & 0.2 & 2.0 & 0.6 & 0.2 & 0.4 & 9.1 & 2730.1 & 1248.4 \\
\hline Insurance of the given and accepted guarantees & 16187.4 & 13507.3 & 5211.4 & -13476.4 & -90127.5 & -77990.6 & -2734.3 & 28063.0 & -64674.2 & -354368.7 & -35254.1 \\
\hline Insurance of medical expenses & 28803.8 & 50348.2 & 85117.9 & 142588.5 & 167797.5 & 213867.0 & 223448.5 & 317915.3 & 323416.6 & 321667.8 & 351768.1 \\
\hline
\end{tabular}

Source: Data of the National Commission for the State Regulation of Financial Services Markets (Bazylevich, 1997).

Table 2. Net insurance payments for certain types of insurance in 2005-2015, thousand UAH

\begin{tabular}{|c|c|c|c|c|c|c|c|c|c|c|c|}
\hline Voluntary types of insurance & 2005 & 2006 & 2007 & 2008 & 2009 & 2010 & 2011 & 2012 & 2013 & 2014 & 2015 \\
\hline Accident insurance & 27360.3 & 19841.2 & 28750.3 & 44622.8 & 37414.7 & 39314.9 & 42524.8 & 51038.7 & 73862.9 & 67483.2 & 48543.1 \\
\hline Medical insurance & 169959.9 & 226709.6 & 324971.4 & 461004.4 & 550694.6 & 632899.6 & 744149.6 & 900811.4 & 1010135.1 & 1108512.8 & 861246.1 \\
\hline Health insurance & 35857.9 & 32589.6 & 29574.3 & 32822.2 & 33348.1 & 38026.6 & 35746.7 & 40662.9 & 66584.7 & 68365.0 & 36631.0 \\
\hline Railway transport insurance & 175.2 & 17.0 & 5.2 & 1.8 & -125.9 & 0.0 & 224.0 & 6480.9 & 2293.8 & 3375.3 & 0.0 \\
\hline Land transport insurance & 510901.4 & 846639.8 & 1647280.1 & 2828225.2 & 2377013.0 & 1693035.6 & 1333441.2 & 1440177.3 & 1514356.0 & 1617455.8 & 1313892.1 \\
\hline Air transport insurance & 1814.8 & 6334.3 & 772.4 & 703.7 & 2879.3 & 2856.4 & 1119.7 & 9022.0 & 7193.9 & 450.5 & 0.0 \\
\hline Water transport insurance & 4526.0 & 6300.2 & 2435.0 & 21639.6 & 12138.6 & 5069.9 & 12433.3 & 28016.7 & 8927.7 & 5245.5 & 1436.6 \\
\hline
\end{tabular}


Table 2 (cont.). Net insurance payments for certain types of insurance in 2005-2015, thousand UAH.

\begin{tabular}{|c|c|c|c|c|c|c|c|c|c|c|c|}
\hline Voluntary types of insurance & 2005 & 2006 & 2007 & 2008 & 2009 & 2010 & 2011 & 2012 & 2013 & 2014 & 2015 \\
\hline Property insurance & 83926.7 & 66734.2 & 73840.1 & 82047.0 & 109710.7 & 133825.2 & 266278.6 & 399751.2 & 137634.1 & 172508.5 & 302616.5 \\
\hline Cargo and baggage insurance & 8677.6 & 3950.9 & 19122.9 & 13195.6 & 12690.4 & 27825.5 & 23784.3 & 50854.7 & 67280.6 & 30395.7 & 64990.7 \\
\hline $\begin{array}{l}\text { Insurance from fire risks and risks of natural } \\
\text { disasters }\end{array}$ & 20998.5 & 42952.8 & 237563.7 & 321246.2 & 160026.0 & 176992.9 & 156681.8 & 143023.1 & 69072.3 & 161725.3 & 59624.1 \\
\hline $\begin{array}{l}\text { Civil liability insurance of the owners of land } \\
\text { transport }\end{array}$ & 10861.8 & 11819.7 & 10294.9 & 10781.8 & 9532.6 & 12834.7 & 15527.1 & 16138.8 & 20608.2 & 19689.5 & 19882.0 \\
\hline $\begin{array}{l}\text { Liability insurance of the owners of air } \\
\text { transport }\end{array}$ & 36.0 & 0.0 & 268.6 & 2.2 & 0.0 & 1192.9 & 0.0 & 399.7 & 26.7 & 2.7 & 25.2 \\
\hline $\begin{array}{l}\text { Liability insurance of the owners of water } \\
\text { transport }\end{array}$ & 362.3 & 132.1 & 186.6 & 259.6 & 160.6 & 1829.5 & 31.4 & 43.9 & 1202.9 & 239.4 & 62.6 \\
\hline Third-party liability coverage & 37270.1 & 22922.0 & 35735.0 & 23186.4 & 15773.6 & 10802.0 & 20661.6 & 24280.9 & 19664.0 & 36514.6 & 16699.6 \\
\hline Credit insurance & 18888.7 & 97648.9 & 223225.0 & 616901.1 & 355114.6 & 151089.8 & 52318.7 & 163904.9 & 98812.5 & 59969.2 & 66149.4 \\
\hline Investment insurance & 0.0 & 0.0 & 0.0 & 0.0 & 0.0 & 0.0 & 0.0 & 0.0 & 203.5 & 0.0 & 0.0 \\
\hline Insurance of financial risks & 388884.4 & 644266.4 & 882411.0 & 1461676.8 & 1577866.5 & 1959133.9 & 840251.5 & 437977.8 & 89251.2 & 41639.9 & 331282.2 \\
\hline Insurance of court expenses & 0.0 & 0.0 & 0.0 & 0.0 & 0.0 & 0.0 & 0.0 & 0.0 & 0.0 & 0.0 & 0.0 \\
\hline $\begin{array}{l}\text { Insurance of the given and accepted } \\
\text { guarantees }\end{array}$ & 281.7 & 23.2 & 0.0 & 0.0 & 0.0 & 848.1 & 1277.8 & 0.0 & 0.0 & 0.2 & 0.0 \\
\hline Insurance of medical expenses & 15701.5 & 24544.0 & 34210.1 & 44810.7 & 72713.6 & 83834.2 & 97780.9 & 120485.2 & 101343.5 & 111065.6 & 113637.6 \\
\hline
\end{tabular}

Source: Data of the National Commission for the State Regulation of Financial Services Markets (Bazylevich, 1997).

Table 3. Indicators of profitability of the voluntary types of insurance in 2005-2015, thousand UAH.

\begin{tabular}{|c|c|c|c|c|c|c|c|c|c|c|c|}
\hline Voluntary types of insurance & 2005 & 2006 & 2007 & 2008 & 2009 & 2010 & 2011 & 2012 & 2013 & 2014 & 2015 \\
\hline Accident insurance & 0.755 & 0.892 & 0.896 & 0.893 & 0.870 & 0.887 & 0.877 & 0.933 & 0.925 & 0.894 & 0.843 \\
\hline Medical insurance & 0.331 & 0.358 & 0.282 & 0.276 & 0.240 & 0.218 & -0.011 & 0.296 & 0.276 & 0.264 & 0.403 \\
\hline Health insurance & 0.559 & 0.652 & 0.734 & 0.801 & 0.737 & 0.726 & 0.706 & 0.871 & 0.821 & 0.773 & 0.818 \\
\hline Land transport insurance & 0.508 & 0.554 & 0.516 & 0.421 & 0.311 & 0.448 & 0.259 & 0.556 & 0.537 & 0.471 & 0.489 \\
\hline Cargo and baggage insurance & 0.985 & 0.992 & 0.964 & 0.981 & 0.966 & 0.965 & 0.964 & 0.946 & 0.930 & 0.965 & 0.946 \\
\hline $\begin{array}{l}\text { Insurance from fire risks and risks of natural } \\
\text { disasters }\end{array}$ & 0.972 & 0.954 & 0.792 & 0.733 & 0.828 & 0.847 & 0.846 & 0.922 & 0.958 & 0.871 & 0.939 \\
\hline Property insurance & 0.915 & 0.944 & 0.952 & 0.950 & 0.926 & 0.920 & 0.741 & 0.847 & 0.945 & 0.916 & 0.813 \\
\hline Third-party liability coverage & 0.804 & 0.899 & 0.874 & 0.947 & 0.968 & 0.979 & 0.934 & 0.974 & 0.981 & 0.946 & 0.978 \\
\hline Credit insurance & 0.949 & 0.710 & 0.627 & 0.477 & 0.523 & 0.411 & 0.718 & 0.671 & 0.856 & 0.846 & 0.692 \\
\hline Insurance of financial risks & 0.736 & 0.569 & 0.468 & -0.047 & -0.743 & -1.593 & 0.332 & 0.791 & 0.963 & 0.979 & 0.817 \\
\hline Insurance of medical expenses & 0.455 & 0.513 & 0.598 & 0.686 & 0.567 & 0.608 & 0.562 & 0.621 & 0.687 & 0.655 & 0.677 \\
\hline
\end{tabular}

Source: Calculated by the author based on the data of the National Commission for the State Regulation of Financial Services Markets (Bazylevich, 1997). 